\title{
Increased neutrophil apoptosis in chronically SIV-infected
} macaques

\author{
Carole Elbim ${ }^{1}$, Valérie Monceaux ${ }^{2}$, Stéphanie François ${ }^{3}$, Bruno Hurtrel2 ${ }^{2}$, \\ Marie-Anne Gougerot-Pocidalo ${ }^{3}$ and Jérome Estaquier*2,4,5
}

Address: ${ }^{1}$ Centre de Recherche des Cordeliers, Université Pierre et Marie Curie - Paris 6, UMR S 872, Paris, F-75006 France; Université Paris Descartes, UMR S 872, Paris, F-75006, France, ${ }^{2}$ Institut Pasteur, Unité de Physiopathologie des Infections Lentivirales, Paris, F-75015, France, ${ }^{3}$ APHP, Centre Hospitalier Universitaire Xavier Bichat, Service d'Immunologie et d'Hématologie, Paris, F-75018, France, ${ }^{4}$ INSERM, U841, Faculté de Médecine de Créteil, Créteil, F-94010, France and ${ }^{5}$ AP-HP, Hôpital Henri Mondor, Créteil, F-94010, France

Email: Carole Elbim - carole.elbim@crc.jussieu.fr; Valérie Monceaux - valerie.monceaux@pasteur.fr; Stéphanie François - francois@inserm.fr; Bruno Hurtrel - bruno.hurtrel@pasteur.fr; Marie-Anne Gougerot-Pocidalo - marianne.pocidalo@bch.aphp.fr;

Jérome Estaquier* - estaquier@yahoo.fr

* Corresponding author

Published: 24 March 2009

Retrovirology 2009, 6:29 doi:10.1186/1742-4690-6-29

This article is available from: http://www.retrovirology.com/content/6/1/29

(c) 2009 Elbim et al; licensee BioMed Central Ltd.

This is an Open Access article distributed under the terms of the Creative Commons Attribution License (http://creativecommons.org/licenses/by/2.0), which permits unrestricted use, distribution, and reproduction in any medium, provided the original work is properly cited.

\begin{abstract}
Polymorphonuclear neutrophils (PMN) from chronically HIV-infected individuals have been reported to be more prone to die. However, although non-human primates models have been extensively used for improving our knowledge on T cell immunity, the impact of SIV-infection on PMN, in relationships with disease severity, has never been assessed. In our study, we demonstrate that PMN from Rhesus macaques (RMs) of Chinese origin chronically infected with the virulent strain SIVmac25I display increased susceptibility to undergo apoptosis as compared to PMN from RMs infected with the non-pathogenic SIV $\Delta$ nef strain. PMN apoptosis was significantly increased in RMs progressing faster to AIDS as compared to non-progressors RMs. Furthermore, the percentage of apoptotic cells correlated with PMN activation state reflected by increased CDI Ib expression and reactive oxygen species production. Interestingly, whereas inflammatory cytokines IL-8 and IL-I $\beta$ prevent in vitro PMN death, the levels of those cytokines were low in RMs progressing towards AIDS. Altogether, increased PMN death during SIV infection is a new pathogenic effect associated with AIDS progression, adding to the long list of markers associated with disruption of defense against infection.
\end{abstract}

\section{Findings}

Polymorphonuclear neutrophils (PMN) are key components of the first line of defense against pathogens [1]. PMN are terminally differentiated cells with a short life span; they die spontaneously by apoptosis and are then recognized and phagocytosed by macrophages [2]. Shortened PMN survival due to apoptosis may explain susceptibility to severe and recurrent infections in some pathological situations $[3,4]$.
It has been reported that PMN functions are impaired in the latter stages of HIV infection [5]; increased PMN apoptosis has also been observed in HIV-infected patients having less than $200 \mathrm{CD} 4^{+}$cells $/ \mathrm{mm}^{3}$ [6-11]; however, the introduction of HAART has reduced spontaneous PMN apoptosis. Several lines of evidence suggest a key role of PMN, at least through defensin expression, in controlling viruses other than HIV or SIV [12-14]. In addition, human neutrophil $\alpha$-defensins $1-4$ have been reported to inhibit 
HIV-1 replication in vitro [15-17], and activated neutrophils have been demonstrated to exert cytotoxic activity against HIV-infected cells[18].

The use of non-human primate models, particularly SIVinfected Rhesus macaques (RMs), has allowed the detailed and sequential investigation of the events of SIV infection in terms of virus dynamics, immune response, and changes in the pool of CD4+ cells [19]. Once the setpoint phase is reached, the level of viral load predicts the rate of progression to AIDS [20-22]. Thus, SIVmac infection of RMs has proved to be an invaluable animal model for studies of AIDS pathogenesis, therapeutics, and vaccines. In particular, we and others have demonstrated that RMs of Chinese origin is a particularly relevant model to study human diseases [23-28]. Paradoxically, no studies have investigated, in SIV-infected RMs, possible PMN dysregulation, especially the propensity of PMNs to die, in relationships with disease severity.

Rhesus macaques (Macaca mulatta, RMs), of Chinese origin background, were confirmed, prior to infection, as seronegative for STLV-1 (Simian T Leukemia Virus type1), SRV-1 (type D retrovirus), herpes-B viruses, and SIVmac. All animals were housed in compliance with French regulations for animal care and usage http://www.pas teur.fr/recherche/unites/animalerie/fichiers/

Decret200486.pdf, and were inoculated intravenously with either pathogenic SIVmac251 strain [ten 50\% animal infectious doses (AID)] or the live attenuated SIVmac251 $\Delta$ nef strain [two hundred 50\% AID].

All the animals were challenged with the same batch of virus, titrated in vivo in rhesus macaques, and were followed post-infection and studied 8 months later. RNA was extracted from plasma of SIV-infected monkeys, using the TRI REAGENT BD Kit (Molecular Research Center Inc., Cincinnati, Ohio). Real-time quantitative reverse tran- scriptase-polymerase chain reaction (RT-PCR) was used to determine viral loads as previously described [22]. Among $\mathrm{SIV}^{+}$macaques, slow progressors $(\mathrm{n}=6)$ and moderate progressors $(n=5)$ were defined according to plasma viral load $\left(<10^{3}\right.$ copies $/ \mathrm{ml}$ and $10^{3}-10^{5}$ copies $/ \mathrm{ml}$, respectively), that predicts further disease progression in RMs of Chinese origin [20,21]. In contrast, in SIVAnef-infected monkeys, plasma viral load was always lower than $1.5 \times$ $10^{2}$ copies $/ \mathrm{ml}$. Moreover, as shown in Table $1, \mathrm{CD} 4^{+} \mathrm{T}$ cell counts were significantly decreased in moderate progressors as compared to $\mathrm{SIV}^{+}$slow progressors, SIV $\Delta$ nef or healthy (SIV-) macaques consistent with previous reports $[20,21]$.

To quantify PMN apoptosis, samples were analyzed directly on the whole blood cooled to $4{ }^{\circ} \mathrm{C}$ to avoid nonspecific activation due to isolation procedure $[29,30]$. PMN apoptosis was measured after 4 hours of incubation in 24-well tissue culture-plates at $37^{\circ} \mathrm{C}$ with $5 \% \mathrm{CO}_{2}$. Apoptosis was quantified by allophycocyanin (APC)-conjugated annexin $\mathrm{V}$ and 7-amino-actinomycin $\mathrm{D}$ (7-AAD) staining as previously described $[29,30]$. Whole blood samples $(100 \mu \mathrm{l})$ were washed twice in PBS, incubated with FITC-anti-CD14 and PE-anti-CD11b monoclonal antibodies (mAbs) for 15 minutes, and then incubated with APC-annexin V for 15 minutes. After dilution in PBS $(500 \mu \mathrm{l})$ the samples were incubated with 7-AAD at room temperature for 15 minutes and analyzed immediately by flow cytometry. PMN were identified as CD $11 b^{+} \mathrm{CD} 14^{\text {low }}$ cells (Figure 1A and 1B).

After 4 hours of incubation at $37^{\circ} \mathrm{C}$, PMN apoptosis was significantly increased in $\mathrm{SIV}^{+}$macaques relative to SIV $\Delta$ nef and healthy controls (Figure 1D). The fact that SIV $\Delta$ nef macaques showed reduced susceptibility to apoptosis as compared to $\mathrm{SIV}^{+}$animals is in keeping with a previous report that the apathogenic strain is associated with milder immune dysfunction and has a lower plasma viral

Table I: Characteristics of the study population a

\begin{tabular}{lcccc}
\hline & $\begin{array}{c}\text { SIV- } \\
(\mathrm{n}=6)\end{array}$ & $\begin{array}{c}\text { SIV } \Delta \text { ef } \\
(\mathrm{n}=4)\end{array}$ & $\begin{array}{c}\text { SIV+ }^{+} \text {slow progressors } \\
(\mathrm{n}=6)\end{array}$ & $\begin{array}{c}\text { SIV+ moderate progressors } \\
(\mathrm{n}=5)\end{array}$ \\
\hline PMN count b & $1840 \pm 259$ & $1693 \pm 325$ & $1956 \pm 252$ & $1685 \pm 245$ \\
Lymphocyte count $^{\mathrm{b}}$ & $3104 \pm 212$ & $2970 \pm 451$ & $3317 \pm 608$ & $2354 \pm 230$ \\
CD4 $^{+}$count b & $1127 \pm 232$ & $1086 \pm 320$ & $848 \pm 149$ & $317 \pm 79 \mathrm{~d}, \mathrm{e}$ \\
CD8 $^{+}$count b & $651 \pm 161$ & $778 \pm 184$ & $1077 \pm 277$ & $1050 \pm 232$ \\
Viral load c & 0 & $1.22 \pm 0.42$ & $38 \pm 19 \mathrm{~d}, \mathrm{e}$ & $1706 \pm 699 \mathrm{~d}, \mathrm{e}, \mathrm{f}$
\end{tabular}

a Monkeys were infected intravenously with $10 \mathrm{AID}_{50}$ of the non-pathogenic nef-deleted SIVmac25I isolate (SIV $\Delta$ nef) or the pathogenic strain SIVmac25I $\left(\mathrm{SIV}^{+}\right)$and were studied 8 months later.

Values are means \pm SEM.

b PMN, lymphocytes, $C D 4^{+}$and $C D 8^{+}$counts are expressed per microliter.

c Viral load is expressed as $10^{2}$ copies per milliliter.

d Significantly different from healthy controls (SIV-) $(p<0.05)$.

e Significantly different from SIV $\Delta$ nef $(p<0.05)$.

${ }^{f}$ Significantly different from $\mathrm{SIV}^{+}$slow progressors $(p<0.05)$. 
A
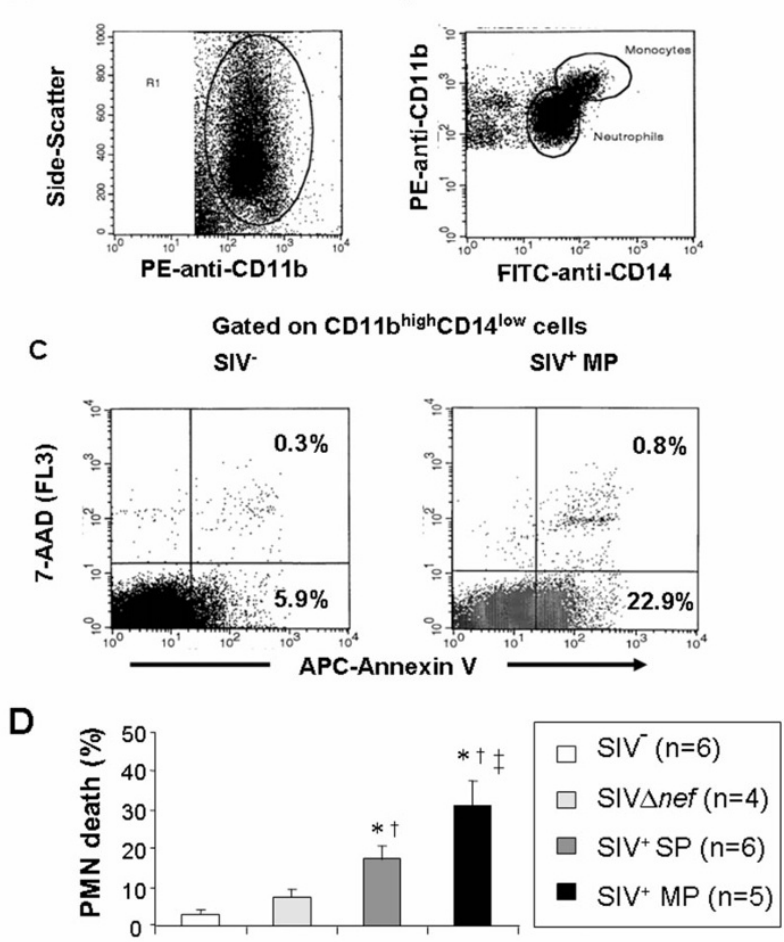

Figure I

PMN apoptosis during chronic infection of rhesus macaques with the pathogenic SIVmac25 I strain. Panels A, B, and $\mathbf{C}$ show the gating strategy to quantify apoptosis. A) Dot plot showing anti-CDI lb-PE staining against the side-scatter parameter. $A$ first gate $(R I)$ was drawn around $C D I$ lb $^{+}$cells. $B$. Dot plot showing antiCDI Ib-PE and anti-CDI4-FITC staining, gated on RI. A second gate (R2) was drawn on CDI $4^{\text {low }}$ cells in order to eliminate monocytes (CDI4high cells) from the analysis. C) The combination of annexin V-APC and 7-AAD staining distinguished early apoptotic cells (annexin $\mathrm{V}^{+}, 7-A A D^{-}$) and late apoptotic cells (annexin $\mathrm{V}^{+}, 7-\mathrm{AAD}^{+}$) in an SIV- macaque and in an $\mathrm{SIV}^{+}$macaque moderate progressor (SIV+ MP) (day 240) after incubating whole blood at $37^{\circ} \mathrm{C}$ for 4 hours (T4h). Panel D. Eleven $\mathrm{SIV}^{+}$(six slow progressors, $\mathrm{SIV}^{+} \mathrm{SP}$ and five moderate progressors, $\mathrm{SIV}^{+} \mathrm{MP}$ ) and four SIV $\Delta$ nef macaques were studied after 8 months of infection. Apoptosis was studied after incubating whole blood at $37^{\circ} \mathrm{C}$ for 4 hours (T4h). Results are expressed as percentage of annexin $\mathrm{V}^{+} / 7$ AAD- cells (early apoptotic cells). Data are reported as means \pm SEM. Comparisons were based on ANOVA and Tukey's posthoc test, using Prism 3.0 software. * Significantly different from healthy controls (SIV- group) $(p<0.05)$; † Significantly different from SIV $\Delta$ nef macaques $(p<0.05)$; †† Significantly different from SIV+SP $(p<0.05)$.

load [31]. Moreover, PMN apoptosis was significantly increased in moderate progressors as compared to slow progressors (percentage of annexin $\mathrm{V}^{+}$cells: $33.0 \pm 5.1$ and $15.7 \pm 1.5$, in moderate and slow progressors respectively). In addition, PMN apoptosis in individual SIV+ macaques correlated negatively with the corresponding CD4+ $\mathrm{T}$ cell counts and positively with plasma viral load ( $\rho=-0.59, p=0.05$ and $\rho=0.91, p=0.0003$, respectively) (correlation was identified by means of the Spearman rank correlation coefficient $\rho$ ). These results suggest that the rate of PMN apoptosisis directly related to the speed of disease progression. In accordance with the general view that many cell types undergo death in a caspase-independent manner [32,33], preincubation of whole blood samples with the broad caspase inhibitor CBz-Val-Ala-DLAsp(Ome)-fluoromethylketone (z-VAD-fmk) (10 $\mu \mathrm{M})$ for 15 minutes did not prevent PMN death in $\mathrm{SIV}^{+}$macaques (data not shown), whereas the same compound prevented Fas-mediated apoptosis of $\mathrm{CD}^{+} \mathrm{T}$ cells in agreement with previous reports $[30,32,34]$. Altogether, these results suggest that $\mathrm{PMN}$ are abnormally primed to undergo death through a caspase-independent pathway in SIV-infected macaques progressing more rapidly to AIDS.

Whereas we found an increased PMN propensity to die, this was not reflected by an apparent decline of PMN counts (Table 1). This result contrasts with our recent data observed during the acute phase of SIV infection in Chinese RM demonstrating that PMN death is associated with neutropenia early after infection [30]. Increased emigration from the bone marrow of mature PMN could be an explanation compensating for the absence of apparent depletion chronically infected macaques. Therefore, we decided to analyze the basal activation status of PMN in the periphery, by measuring CD11b expression and ROS production. Superoxide anion $\mathrm{O}_{2}$ - production was measured with a flow cytometric assay derived from the hydroethidine (HE) oxidation technique [29,30].

Both CD11b expression (Figure 2A) and ROS production (Figure $2 \mathrm{~B}$ ) of resting PMN (maintained at $4{ }^{\circ} \mathrm{C}$ ) were significantly increased in both slow and moderate progressors relative to healthy and SIV $\Delta$ nef controls. Furthermore, PMN from moderate progressors exhibited increased CD11b expression and ROS production as compared to slow progressors. Interestingly, the percentage of apoptotic cells correlated with basal PMN activation status $(\rho=$ $0.69, \mathrm{p}=0.01$ and $\rho=0.71, \mathrm{p}=0.01$, for CD11b expression and ROS production, respectively). The consequences of PMN activation generating general oxidative stress molecules might include an increased PMN susceptibility to apoptotic death during the chronic phase of infection [35]. In addition, these results support the idea that increased granulopoiesis in bone marrow leads to a compensatory release of mature PMN. Interestingly, PMN activation has been reported in the bone marrow of chronically SIV-infected macaques [36], contrasting with a defect in bone marrow lymphopoiesis $[37,38]$. Infact, reciprocal dynamics of the bone marrow lymphocyte and neutrophil populations lead to cellular competition within a developmental niche. In particular, blocking 
A

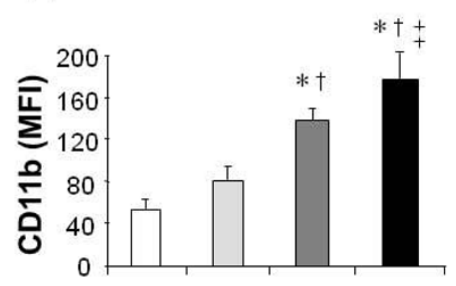

B

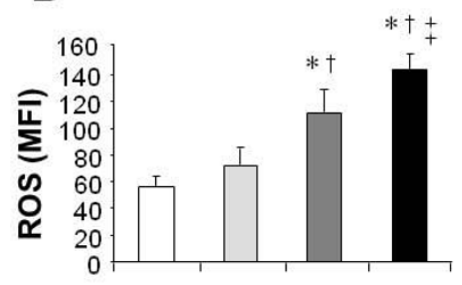

Figure 2

PMN functions during chronic infection of rhesus macaques with the pathogenic SIVmac25 I strain or the attenuated SIV $\Delta$ nef strain. Basal CDI Ib expression on the PMN surface (A) and basal ROS production (B) were studied in whole blood samples. Results are expressed as Mean Fluorescence Intensity (MFI). Data are reported as means \pm SEM. Comparisons were based on ANOVA and Tukey's posthoc test, using Prism 3.0 software. * Significantly different from healthy controls (SIV- group) ( $p<0.05)$; † Significantly different from SIV $\Delta$ nef macaques $(p<0.05)$; t† Significantly different from SIV+ SP $(p<0.05)$.

bone marrow lymphopoiesis results in the specific and reciprocal expansion of the granulocytic compartment in bone marrow [39].

Our results showed that, at 8 months post-inoculation (p.i.), the extent of PMN apoptosis is higher than that observed at 2 months p.i., while the levels of viral replication remain quite similar [30]. In addition, during the acute phase, the levels of $10^{7}$ copies/ml in RMs infected with the pathogenic strain is associated with PMN death; interestingly in RMs infected with the live attenuated $\Delta n e f$ strain, despite a viral load of $10^{5}$ copies $/ \mathrm{ml}$ at the peak (day 14 p.i.), no PMN death was observed [30]. This level of viral replication corresponds to that observed during the chronic phase. Altogether, these data suggest that, while a certain threshold of viral particles is required for a direct effect on cell death, extracellular factors could participate in PMN dysregulation. Because it has been shown that inflammatory cytokines inhibit PMN apoptosis $[40,41]$, we then determined in the plasma the amount of IL- 8 , TNF- $\alpha$, and IL- $1 \beta$. Blood was collected in sterile EDTA-treated vacuum tubes and immediately centrifuged at $400 \mathrm{~g}$ for 15 minutes at $4{ }^{\circ} \mathrm{C}$. IL- 8 , TNF- $\alpha$, and IL- $1 \beta$ were detected simultaneously by using the human inflam- matory cytokine cytometric bead array (CBA) kit (BD Pharmingen), which has been validated for cytokine measurements in RMs after Toll-like receptor (TLR) stimulation (data not shown).

Firstly, we found that IL- 8 and IL- $1 \beta$ plasma levels were significantly lower in $\mathrm{SIV}^{+}$moderate progressors as compared to $\mathrm{SIV}^{+}$slow progressors and SIV $\Delta$ nef macaques (Figure 3A). Secondly, pre-incubation of whole blood samples from moderate progressors with IL-8 $(100 \mathrm{ng} / \mathrm{ml})$ or IL-1 $\beta(100 \mathrm{ng} / \mathrm{ml})$ for 4 hours significantly reduced PMN apoptosis as compared to samples incubated with PBS [percentage of annexin $\mathrm{V}^{+}$cells: $8.2 \pm 1.3,9.5 \pm 2.1$ and $18.5 \pm 4.3$ for the samples incubated with IL-8, IL-1 $\beta$ (R\&D), or PBS, respectively] (Figure 3B). In contrast, TNF$\alpha$ was undetectable in the plasma of SIV-infected

\section{A}

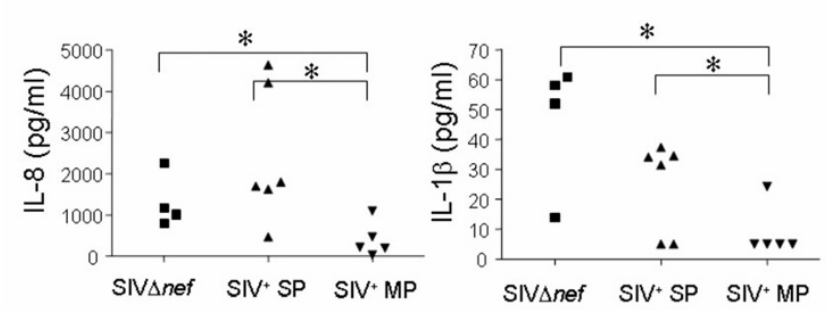

B

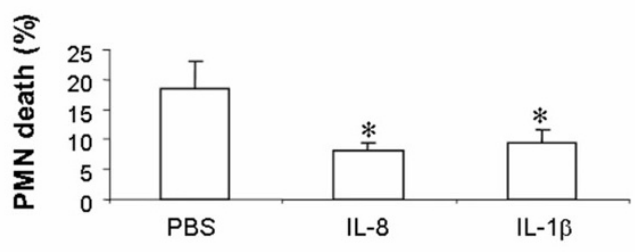

Figure 3

Levels of pro-inflammatory cytokines during chronic infection of rhesus macaques with the pathogenic SIVmac25 I strain. A) IL-8 and IL- I $\beta$ levels during chronic infection of rhesus macaques with the pathogenic SIVmac25 I strain (slow progressors SIV $\mathrm{SP}^{+}$, and moderate progressors, $\mathrm{SIV}^{+} \mathrm{MP}$ ) or the attenuated SIV $\Delta$ nef strain. Plasma levels of IL8 and IL-I $\beta$ were measured by using the inflammatory cytokine cytometric bead array (CBA).* Significantly different $(p<0.05)$. B) Effect of IL-8 and IL-I $\beta$ on PMN survival.

Whole blood samples from $\mathrm{SIV}^{+}$rhesus macaques were incubated at $37^{\circ} \mathrm{C}$ for 4 hours either with IL-8 (100 ng/ml), IL-I $(100 \mathrm{ng} / \mathrm{ml})$ or PBS. Results are expressed as percentage of annexin $\mathrm{V}^{+} / 7-A A D$ - cells (early apoptotic cells). Data are reported as means \pm SEM. Comparisons were based on ANOVA and Tukey's posthoc test, using Prism 3.0 software. * Significantly different from samples incubated with PBS alone $(p<0.05)$. 
macaques. The absence of detection of TNF- $\alpha$ in chronically SIV-infected rhesus macaques is consistent with a recent report [42]. Indeed, the authors did not observe increased levels of pro-inflammatory cytokines despite increased levels of plasma LPS. Thus, the absence of inflammatory cytokines might lead to an abnormal tendency of PMN to die.

Finally, one consequence of such abnormal PMN apoptosis could be to facilitate the dissemination of SIV/HIV in vivo by modulating immune responses. Apoptotic cells are sources of biologically active oxidized phospholipids which serve as recognition signals on apoptotic cells, facilitating phagocytosis by macrophages [43]. Engulfment of apoptotic PMN has been shown to inhibit the production of pro-inflammatory mediators by macrophages, through the secretion of anti-inflammatory cytokines such as TGF$\beta$ [44]. In this context, we recently demonstrated that TGF$\beta$ is increased in the tissues of SIV-infected RMs [25]. Such anti-inflammatory events can inhibit antigen presentation and promote microbial growth within macrophages [45], HIV replication [46], as well as the expansion of IL-17producing cells [47].

In conclusion, our data demonstrate for the first time, to our knowledge, in SIV-infected macaques abnormal PMN deaths that increased in monkeys progressing faster to AIDS. This abnormality might therefore participate in the general immune defect leading to clinical outcomes in SIV infection.

\section{Competing interests}

The authors declare that they have no competing interests.

\section{Authors' contributions}

$\mathrm{CE}, \mathrm{BH}, \mathrm{MAGP}$ and JE designed the study. CE and SF performed neutrophil studies and the statistical analysis; VM performed viral load measurements. VM participated in the design of the study and performed viral load measurements. CE and JE wrote the manuscript. All authors read and approved the manuscript.

\section{Acknowledgements}

This work was funded by grants from the Agence Nationale de Recherches sur le Sida et les Hépatites Virales (ANRS). CE holds an AP-HP mobility post-doctoral position. SF was supported by a grant from Fonds d'études et de recherche du corps médical des Hôpitaux de Paris. This work is dedicated to the memory of Bruno Hurtrel.

\section{References}

I. Babior BM: Oxidants from phagocytes: agents of defense and destruction. Blood 1984, 64:959-966.

2. Savill J, Dransfield I, Gregory C, Haslett C: A blast from the past: clearance of apoptotic cells regulates immune responses. Nat Rev Immunol 2002, 2:965-975.

3. Aleman M, Schierloh P, de la Barrera SS, Musella RM, Saab MA, Baldini $M$, Abbate E, Sasiain MC: Mycobacterium tuberculosis triggers apoptosis in peripheral neutrophils involving Toll-Like
Receptor 2 and p38 mitogen protein kinase in tuberculosis patients. Infect Immun 2004, 72:5I50-5I 58.

4. Ramirez MJ, Titos E, Claria J, Navasa M, Fernandez J, Rodes J: Increased apoptosis dependent on caspase-3 activity in polymorphonuclear leukocytes from patients with cirrhosis and ascites. J Hepatol 2004, 41:44-48.

5. Elbim C, Prevot MH, Bouscara F, Franzini E, Chollet-Martin S, Hakim J, Gougerot-Pocidalo MA: PMN from HIV-infected patients show enhanced activation, diminished fMLP-induced L-selectin shedding and an impaired oxidative burst after cytokine priming. Blood 1994, 84:2759-2766.

6. Baldelli F, Preziosi R, Francisci D, Tascini C, Bistoni F, Nicoletti I: Programmed granulocyte neutrophil death in patients at different stages of HIV infection. AIDS 2000, 214:1067-1069.

7. Lichtner M, Mengoni F, Mastroianni CM, Sauzullo I, Rossi R, De Nicol $M$, Vullo V, Ghibelli L: HIV protease inhibitor therapy reverses neutrophil apoptosis in AIDS patients by direct calpain inhibition. Apoptosis 2006, I I:78I-787.

8. Mastroianni CM, d'Ettore G, Forcina G, Lichtner M, Mengoni F, D'Agostino C, Corpolongo A, Massetti AP, Vullo V: Interleukin-I5 enhances neutrophil functional activity in patients with human immunodeficiency virus infection. Blood 2000, 96: 1979-1984.

9. Mastroianni CM, Mengoni F, Lichtner M, D'Agostino C, d'Ettorre G, Forcina G, Marzi M, Russo G, Massetti AP, Vullo V: Ex vivo and in vitro effect of human immunodeficiency virus protesase inhibitors on neutrophil apoptosis. J Infect Dis 2000, 182:1536-1539.

10. Pitrak DL, Tsai HC, Mullane KM, Sutton SH, Stevens P: Accelerated neutrophil apoptosis in the acquired immunodeficiency syndrome. J Clin Invest 1996, 98:27|4-27/9.

II. Salmen S, Teran G, Borges L, Goncalves L, Albarràn B, Urdaneta H, Montes H, Berrueta $L$ : Increased Fas-mediated apoptosis in polymorphonuclear cells from HIV-infected patients. Clin Exp Immunol 2004, 137: 166-I72.

12. Bastian A, Schafer H: Human alpha-defensin I (HNP-I) inhibits adenoviral infection in vitro. Regul Pept 200I, I0I:157-161.

13. Fujisawa $\mathrm{H}$ : Inhibitory role of neutrophils on influenza virus multiplication in the lungs of mice. Microbiol Immunol 200I, 45:679-688.

14. Yasin B, Wang W, Pang M, Cheshenko N, Hong T, Waring AJ, Herold $B C$, Wagar EA, Lehrer RI: Theta defensins protect cells from infection by herpes simplex virus by unhibiting viral adhesion and entry. J Virol 2004, 78:5I47-5I56.

15. Wu Z, Cicchi F, Gentles D, Ericksen B, Lubkowski J, Devico A, Lehrer RI, Lu W: Human neutrophil alpha-defensin 4 inhibits HIV-I infection in vitro. FEBS Lett 2005, 579:162-166.

16. Zhang L, Yu W, He T, Caffrey RE, Dalmasso EA, Fu S, Pham T, Mei J, Ho JJ, Zhang W, Lopez P, Ho DD: Contribution of human alphadefensin I, 2, and 3 to the anti-HIV-I activity of CD8 antiviral factor. Science 2002, 298:995-1000.

17. Zhang L, Lopez P, He T, Yu W, Ho DD: Retraction of an interpretation. Science 2004, 303:467.

18. Baldwin GC, Fuller D, Roberts RL, Ho DD, Golde DW: Granulocyte- and granulocyte-macrophage colony-stimulating factors enhance neutrophil cytotoxicity toward HIV-infected cells. Blood 1989, 74:1673-1677.

19. Hurtrel B, Petit F, Arnoult D, Muller-Trutwin M, Silvestri G, Estaquier J: Apoptosis in SIV infection. Cell Death Differ 2005, I 2(Suppl I):979-990.

20. Monceaux V, Ho Tsong Fang R, Cumont MC, Hurtrel B, Estaquier J: Distinct cycling $\mathrm{CD4}^{+}$and $\mathrm{CD8}^{+} \mathrm{T}$ cell profiles during the asymptomatic phase of simian immunodeficiency virus SIVmac25 I infection in rhesus macaques. J Virol 2003, 77:10047-10059.

21. Monceaux V, Viollet L, Petit F, Ho Tsong Fang R, Cumont MC, Zaunders J, Hurtrel B, Estaquier J: $\mathbf{C D 8}^{+} \mathbf{T}$ cell dynamics during primary simian immunodeficiency virus infection in Macaques: Relationship of effector cell differenciation with the extent of viral replication. J Immunol 2005, 174:6898-6908.

22. Watson A, Ranchalis J, Travis B, McClure J, Sutton W, Johnson PR, Hu $\mathrm{SL}$, Haigwood NL: Plasma viremia in macaques infected with simian immunodeficiency virus: plasma viral load early in infection predicts survival. J Virol 1997, 71 :284-290.

23. Monceaux V, Estaquier J, Février $M$, Cumont $M C$, Rivière $Y$, Aubertin AM, Ameisen JC, Hurtrel B: Extensive apoptosis in lymphoid 
organs during primary SIV infection predicts rapid progression towards AIDS. AIDS 2003, I7:1585-1596.

24. Monceaux V, Viollet L, Petit F, Cumont MC, Kaufmann GR, Aubertin AM, Hurtrel B, Silvestri G, Estaquier J: CD4 ${ }^{+}$CCR5+T-Cell $^{+}$ Dynamics during Simian Immunodeficiency Virus Infection of Chinese Rhesus Macaques. J Virol 2007, 8I:I 3865-I 3875.

25. Cumont MC, Monceaux V, Viollet L, Lay S, Parker R, Hurtrel B, Estaquier J: TGF-beta in intestinal lymphoid organs contributes to the death of armed effector CD8 T cells and is associated with the absence of virus containment in rhesus macaques infected with the simian immunodeficiency virus. Cell Death Differ 2007, I 4: 1747-I758.

26. Cumont MC, Diop O, Vaslin B, Elbim C, Viollet L, Monceaux V, Lay S, Silvestri G, Le Grand R, Müller-Trutwin M, Hurtrel B, Estaquier J: Early divergence inlymphoid tissue apoptosis between pathogenic and nonpathogenic simian immunodeficiency virus infections of nonhuman primates. I Virol 2008, 82: | I75-। I 78 .

27. Ling B, Veazey RS, Luckay A, Penedo C, Xu K, Lifson JD, Marx PA SIV (mac) pathogenesis in rhesus macaques of Chinese and Indian origin compared with primary HIV infections in human. AIDS 2002, 16: I 489-1496.

28. Reiman KA, Parker RA, Seaman MS, Beaudry K, Beddall M, Peterson L, Williams KC, Veazey RS, Montefiori DC, Mascola JR, Nabel G], Letvin NL: Pathogenicity of simian-human immunodeficiency virus SHIV-89.6P and SIVmac is attenuated in cynomolgus macaques and associated with early T-lymphocyte responses. J Virol 2005, 79:8878-8885.

29. François S, El Benna J, Dang PMC, Pedruzzi E, Gougerot-Pocidalo MA, Elbim C: Inhibition of neutrophil apoptosis by Toll-like receptor agonists in whole blood: involvement of the phosphoinositide 3-kinase/Akt and NF-kB signaling pathways leading to increased levels of Mcl-I, AI and phosphorylated Bad. J Immunol 2005, 174:3633-3642.

30. Elbim C, Monceaux V, Mueller YM, Lewis MG, François S, Diop O Akarid K, Hurtrel B, Gougerot-Pocidalo MA, Levy Y, Katsikis PD, Estaquier J: Early divergence in neutrophil apoptosis between pathogenic and non- pathogenic SIV infections of nonhuman primates. J Immunol 2008, 181:8613-8623.

31. Ho Tsong Fang R, Khatissian E, Monceaux V, Cumont MC, Beq S, Ameisen JC, Aubertin AM, Israël N, Estaquier J, Hurtrel B: Disease progression in macaques with low SIV replication levels: on the relevance of TREC counts. AIDS 2005, 19:663-673.

32. Arnoult D, Petit F, Lelievre JD, Lecossier D, Hance A, Monceaux V, Hurtrel B, Ho Tsong Fang R, Ameisen JC, Estaquier J: Caspasedependent and -independent T-cell death pathways in pathogenic simian immunodeficiency virus infection: relationship to disease progression. Cell Death Differ 2003, 10:1240-I252.

33. Chipuk JE, Green DR: Do inducers of apoptosis trigger caspaseindependent cell death? Nat Rev Mol Cell Biol 2005, 6:268-275.

34. Viollet L, Monceaux V, Petit F, Ho Tsong Fang R, Cumont MC Hurtrel B, Estaquier J: Death of CD4+ T cells from lymph nodes during primary SIVmac25 I infection predicts the rate of AIDS progression. J Immunol 2006, 177:6685-6694.

35. Von Gunten S, Yousefi S, Seitz M, Jakob SM, Schaffner T, Seger R Takala J, Villiger PM, Simon HU: Siglec-9 transduces apoptotic and nonapoptotic death signals into neutrophils depending on the proinflammatory cytokine environment. Blood 2005, 106: $|423-143|$.

36. Silvestri G, Sodora DL, Koup RA, Paiardini M, O'Neil SP, McClure H, Staprans SI, Feinberg MB: Nonpathogenic SIV infection of sooty mangabeys is characterized by limited bystander immunopathology despite chronic high-level viremia. Immunity 2003, 18:441-452.

37. Thiebot H, Louache F, Vaslin B, de Revel T, Neildez O, Larghero J, Vainchenker W, Dormont D, Le Grand R: Early and persistent bone marrow hematopoiesis defect in Simian/Human Immunodeficy Virus-infected macaques despite efficient reduction of viremia by highly active antiretroviral therapy during primary infection. J Virol 2001, 75:1 I594-11602.

38. Thiebot H, Vaslin B, Derdouch S, Bertho JM, Mouthon F, Prost S, Gras G, Ducouret P, Dormont D, Le Grand R: Impact of bone marrow hematopoiesis failure on T-cell generation during pathogenic simian immunodeficiency virus infection in macaques. Blood 2005, 105:2403-2409.
39. Ueda Y, Kondo M, Kelsoe G: Inflammation and the reciprocal production of granulocytes and lymphocytes in bone marrow. J Exp Med 2005, 20 I: I 77I-I780.

40. Colotta F, Re F, Polentarutti N, Sozzani S, Mantovani A: Modulation of granulocyte survival and programmed cell death by cytokines and bacterial products. Blood 1992, 80:20I2-2020.

4I. Cowburn AS, Deighton J, Walmsley SR, Chilvers ER: The survival effect of TNF-alpha in human neutrophils is mediated via NF-kappa B-dependent IL-8 release. Eur J Immunol 2004, 34: 1733-1743.

42. Brenchley JM, Price DA, Schacker TW, Asher TE, Silvestri G, Rao S, Kazzaz Z, Bornstein E, Lambotte O, Altmann D, Blazar BR, Rodriguez B, Teixeira-Johnson L, Landay A, Martin JN, Hecht FM, Picker LJ, Lederman MM, Deeks SG, Douek DC: Microbial translocation is a cause of systemic immune activation in chronic HIV infection. Nature Medicine 2006, I 2:1365-137I.

43. Kadl A, Bochkov VN, Huber J, Leitinger N: Apoptotic cells as sources for biologically active oxidized phospholipids. Antioxid Redox Signal 2004, 6:3I I-320.

44. Huynh ML, Fadok VA, Henson PM: Phosphatidylserine-dependent ingestion of apoptotic cells promotes TGF- $\beta$ I secretion and the resolution of inflammation. J Clin Invest 2002, I09:4I-50.

45. Laskay T, van Zandbergen G, Solbach W: Neutrophil granulocytes Trojan horses for Leishmania major and other intracellular microbes? Trends Microbiol 2003, II:2/0-2/4.

46. Lima RG, Weyenberg JV, Saraiva EMB, Barral-Netto M, Galvão-Castro B, Bou-Habib DC: The replication of human immunodeficiency virus type $I$ in macrophages is enhanced after phagocytosis of apoptotic cells. J Infect Dis 2002, 185: I 56I- I 566.

47. Stark MA, Huo Y, Burcin TL, Morris MA, Olson TS, Ley K: Phagocytosis of apoptotic neutrophils regulates granulopoiesis via IL23 and IL-I7. Immunity 2005, 88:285-294.

Publish with Biomed Central and every scientist can read your work free of charge

"BioMed Central will be the most significant development for disseminating the results of biomedical research in our lifetime. "

Sir Paul Nurse, Cancer Research UK

Your research papers will be:

- available free of charge to the entire biomedical community

- peer reviewed and published immediately upon acceptance

- cited in PubMed and archived on PubMed Central

- yours - you keep the copyright 